Електронне наукове фахове видання "Ефективна економіка" включено до переліку наукових фахових видань України з питань економіки (Категорія «Б», Наказ Міністерства освіти і науки України від 11.07.2019 № 975) www.economy.nayka.com.ua| № 5, 2021 | 27.05.2021 p.

DOI: $\underline{10.32702 / 2307-2105-2021.5 .70}$

УДК 332.14

\begin{abstract}
T. Topolnytska
PhD in Economics,

Associate Professor of the Department of Theory of Economics and Management, Ivano-Frankivsk National Technical University of Oil and Gas, Ivano-Frankivsk

ORCID ID: 0000-0003-0125-542X

R. Matskiv

PhD in Economics, Associate Professor,

Associate Professor of the Department of Theory of Economics and Management, Ivano-Frankivsk National Technical University of Oil and Gas, Ivano-Frankivsk ORCID ID: 0000-0002-2966-6012
\end{abstract}

S. Pobihun

PhD in Economics, Associate Professor,

Associate Professor of the Department of Entrepreneurship and Marketing, Ivano-Frankivsk National Technical University of Oil and Gas, Ivano-Frankivsk ORCID ID: 0000-0002-2809-3312

\title{
REGION IMAGE FORMATION BY USING SOCIAL COMMUNICATIONS
}

\section{Т. Б. Топольницька,}

к. е. н., дочент кафедри теорії економіки та управління, Івано-Франківський національний технічний університет нафти і газу

P. T. Мацьків,

к. е. н., дочент, дочент кафедри теорії економіки та управління, Івано-Франківський національний технічний університет нафти і газу С. А. Побігун,

к. е. н., доцент, доцент кафедри підприємництва та маркетингу, Івано-Франківський національний технічний університет нафти і газу

\section{ФОРМУВАННЯ ІМІДЖУ РЕГІОНУ ЧЕРЕЗ СОЦАЛЬНІ КОМУНІКАЦЇ̈}

The need to form the competitive advantages of the regions determines the feasibility of forming new tools for managing their socio-economic development, one of which is the formation of the image of the regions with the use of social communications. The study substantiates that the development of social communications is an important factor in the process of forming the image of the region. Interest in the image arises from the stimulating opportunities, the impact of the image on the economy and social sphere of the region through social communications and the formation of a favorable information environment. Emphasis is placed on the development of the theory of the 
region's image in combination with such concepts as "communication", "information" and "information exchange". The necessity of application of marketing tools for realization of process of formation of image of region is argued. The stages of preparation of marketing strategy of image formation of the region are highlighted: situation analysis, goal setting, market segmentation, market research, positioning and branding, selection of marketing tools, development of evaluation tools, budget preparation, strategy development and implementation plan. The main groups of the target audience in the formation of the image of the region are identified. It is noted that local media perform those functions that cannot be performed by the central media. They are responsible for preserving and developing the identity of the region, forming public opinion, ensuring the consolidation of the territory and forming a sense of belonging to it, creating and maintaining a positive image of the region. A separate issue is the aspect of using digital and interactive technologies in the formation of the image of the regions. Factors that will ensure the successful implementation of the process of forming the image of the region are identified. The existence of a relationship between the positive image of the region and the achievement of sustainable development goals is substantiated. The study found that the use of social communication tools will create a unique image of the region on the basis of its competitive advantages, develop the business environment of the region and attract the resources needed for effective regional development.

Необхідність формування конкурентних переваг регіонів зумовлює дочільність формування нових інструментів управління їх сочіально-економічним розвитком, одним з яких $\epsilon$ формування іміджу регіонів з використанням сочіальних комунікацій. У дослідженні обтрунтовано, щз розвиток сочіальних комунікаиій виступає вагомим фактором у процесі формування іміджу регіону. Зацікавленість іміджем постає з боку стимулюючих можливостей, впливовості іміджу на економіку та соиіальну сферу регіону за рахунок соціальних комунікачій та формування сприятливого інформаційного середовища. Акцентовано увагу на розвитку теорії іміджу регіону в комплексі з такими поняттями як «комунікачія», «інформація» та «інформачійний обмін». Аргументовано необхідність застосування маркетингового інструментарію для реалізаиії прочесу формування іміджу регіону. Виділено етапи підготовки маркетингової стратегії формування іміджу регіону: аналіз ситуації, визначення иілей, сегментація ринку, проведення ринкового дослідження, позииіонування та брендинг, вибір набору інструментів маркетингу, розробка інструментарію оцінювання, підготовка бюджету, розробка стратегї та плану ї̈ впровадження. Ідентифіковано основні групи иільової аудиторії у формуванні іміджу регіону. Зазначено, що локальні медіа виконують ті функиії, які не можуть будуть виконані центральними засобами масової інформації. На них покладена відповідальність за збереження й розвиток ідентичності регіону, формування громадської думки, забезпечення консолідованості територї й формування почуття належності до неї, створення ци постійне підтримання позитивного іміджу регіону. Окремим питанням розглянуто аспект використання у формуванні іміджу регіонів цифрових та інтерактивних технологій. Виділено фактори, які забезпечать успішну реалізачію прочесу формування іміджу регіону. Обтрунтована наявність взаємозв'язку між позитивно побудованим іміджем регіону та досягненням иілей сталого розвитку. У ході дослідження встановлено, щзо використання інструментів сочіальної комунікації дасть змогу створювати унікальний образ регіону на засадах формування його конкурентних переваг, розвивати бізнес-середовище регіону та залучати ресурси, необхідні для ефективного регіонального розвитку.

Key words: region image; socio-economic development of the region; social communications; information environment; interactive technologies. 
Ключові слова: імідж регіону; сочіально-економічний розвиток регіону; соціальні комунікаиї; інформаційне середовище; інтерактивні технологї.

Problem statement. Active processes of globalization and decentralization reform in Ukraine, characterized by the free movement of tangible and intangible resources in order to find the most profitable areas of their application, have given territorial communities additional opportunities for development. At the same time, due to this, there is an intensification of competition between regions for resources, investments and people. Therefore, cities and other settlements are interested in conveying information about themselves to both the local population and other stakeholders. Only now are the processes of gaining relevant experience in new conditions, in particular, communication - information exchange with their own community and the external environment [1].

The need to form the competitive advantages of the regions, based on the use of the priorities of the new, innovative, information economy, determines the feasibility of creating a positive image of the region with the use of social communications. The use of these tools will create a unique region image based on the formation of its competitive advantages, develop the business environment of the region and attract the resources necessary for effective regional development.

Analysis of recent research and publications. In the modern scientific literature on the problems of territorial image-making, approaches to the concept of "image of the region" are considered from different positions. Quite often in scientific works the study of the image of the territory takes place in a complex combination with such concepts as "communication", "information" and "information exchange". Among them, of particular interest in the context of our study are the works of those authors who emphasize the need to take into account information and means of its dissemination and the impact of communication processes on the image of the region, in particular:

Vasilkonova E. [2] formulated the author's vision of the region image as a purposefully formed informationfilled image that reflects the regional economic complex in the unity of economic, social, cultural, communication processes, which are recognized in the environment as the most common characteristics repeated over time and confirmed in the facts of target and non-target positioning by the population of the region;

Shoturma N. [3] understands the regional image as a single image of the region, which was formed in the minds of certain citizens on the basis of their own experience or as a result of a number of purposeful information contacts within the implementation of information policy to create an idea of it in the mass consciousness;

Szromnik A. [4] claims that an image of a region is the whole of subjective imaginings of the reality which originated in human minds as a consequence of perception, influence of mass media and informal information transfer;

Sadovyi V., Mohylna N., Omelianenko V. [5] regional image is understood as a holistic symbolic representation of the region, formed in the minds of the target audience on the basis of personal experience or as a result of a number of purposeful information influences in the context of information strategy for mass formation. consciousness of the idea of the region;

The image of the region is not the newest concept of modernity, but right now its research is gaining more and more relevance. One of the most important tools for image formation are communication elements. The emergence of the phenomenon of a new role of public opinion, which cannot be ignored, contributed to the significant influence of communication technologies on the formation of the image of territories, in addition to the fact that humanity is oriented towards information civilization.

Formulation of the goals of the article (task statement). The aim of the article is to study the process of forming a positive image of the region under the influence of modern tools of social communications.

Presentation of the main research material. Today, the image occupies a special place in the information policy of the region. The goal of regional authorities, population, business community is to form a positive image and reputation, which will have the ability to distinguish them along with other regions of the country and the regions of other countries. This is an element of competition that provides incentives in the implementation of various functions of regional governance. First of all, it is a function of information support, its qualitative and quantitative content [2].

Unsuccessfully constructed image, or one that arose involuntarily, can become the basis of the strongest information failures in communication processes between the population of the region and external communities, the destruction of the characteristics of the imaginary community and, ultimately, the atomization of society, destruction or destabilization of its institutional structure. social identity not only territorial but also social identity in general.

The process of forming the image of the region is a set of measures aimed at creating the image of the territory through the formation of awareness, interest and interest among different groups of the target audience. The main groups of the target audience in shaping the image of the region are:

- investors - those who are looking for opportunities;

- entrepreneurs - those who are looking for labor and new business opportunities;

- partners - those who seek mutually beneficial cooperation;

- locals - those who are looking for a better life; 
- tourists - those who are looking for new experiences [7].

The image of the region is formed in the representation of different groups of the target audience as a set of images, associations and expectations. It is a rational or emotional value that is formed in the process of relationship with the consumer. The image reflects the unique characteristics of the region, its charms, which have gained public recognition and have a stable demand among the target audience. A successful image is necessarily dynamic and indicates development: it not only shows the current state of the region, but also gives an idea of what it will be like in the future.

The subjects of creating the image of the region are the administration of the region, the media, leading figures of various sectors of society, settlements that are part of a particular region. The effectiveness of the image of the region is characterized by the professionalism of the subjects who influence it. The purpose of the image-making of the region is to establish mutual understanding and cooperation between citizens and the authorities, which are in a single information and geographical space, to create territorial uniqueness [3].

When forming the image of the region, it is necessary to apply a systematic approach that would create a single system of territorial development and ensure the relationship between the formation of the image of the region and the overall strategy of development of the territory and the algorithm of its implementation. For the practical implementation of these provisions, it is necessary to use marketing tools, which is an effective method of supporting local economic development and attracting investment.

The process of marketing the image of the region includes two main stages: positioning and promotion (Fig. 1). Positioning in the market sense is the reproduction of an attractive image of a product, product or service, which increases its competitiveness. Any region should be considered as a specific product, consumers of useful properties of which are residents, investors, entrepreneurs, tourists, etc. [6]. If we talk about the positioning of the region, we must first determine the strongest and most exceptional characteristics of the territory, which will later be used to form its unique position. The image of the region should be as focused as possible on the advantages of the territory and clearly reflect the available resources. Next is promotion, which helps to skillfully express themselves to the selected target audience, taking into account their own marketing goals: attracting investment, increasing the flow of tourists, strengthening the commitment of residents and others.

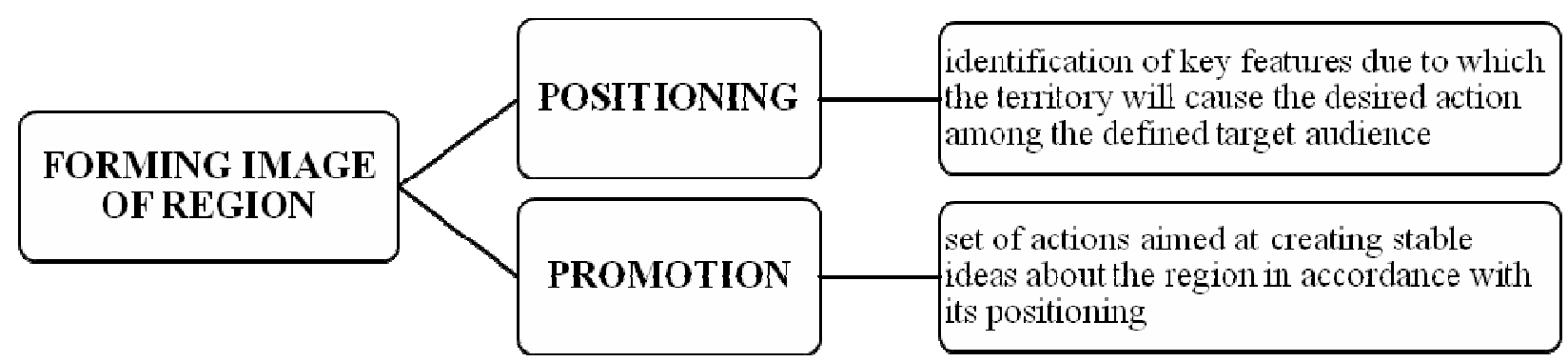

Fig. 1. The process of forming the image of the region. Source: developed by the authors based on [2; 7].

The use of marketing technologies in the process of promoting the image of the region involves the development and dissemination of purposefully constructed image through the development of a marketing strategy developed for the region. Forming the image of the region is not a one-time project or list of actions, it is a certain approach and attitude. This is a permanent process, as the image of the region is characterized by such properties as variability, relative stability, complexity, diversity of perception, dependence on the indicators of development of the region.

Experience shows that effective marketing activities are not accidental, but are part of a comprehensive and consistent strategy. However, there is no single successful approach, as each region has its own unique conditions and resources. We propose to allocate 9 stages in preparation of marketing strategy of formation of image of region [2; 7; 8; 9]:

1. Situation analysis:

- identify key benefits and problems of the region;

- to explore the existing image of the region and its presence in the information space.

2. Defining goals:

- to find out what result the territorial community wants to achieve;

- determine the identity of the territory and identity indicators.

3. Market segmentation:

- identify the main groups of the target audience; 
- divide the target audience into groups.

4. Conducting market research:

- analyze the needs and desires of each group of the target audience;

- identify the strengths and weaknesses of competitors.

5. Positioning and branding:

- to form the concept of the target image and brand of the region;

- prepare a technical obstacle for brand visualization.

6. Choosing a set of marketing tools:

- choose channels and tools of marketing communication;

- identify key messages.

7. Development of evaluation tools:

- formulate indicators to track the implementation of planned marketing goals;

- choose quantitative and qualitative indicators that will assess the formation of the image.

8. Budget preparation:

- determine the cost of each stage and prioritize costs;

- identify sources of funding.

9. Development of strategy and plan for its implementation:

- to determine the persons responsible for the implementation of marketing activities and projects;

- implementation of the strategy as a policy of the region.

An action plan for the implementation of the marketing strategy should be drawn up and implemented gradually, providing an opportunity to assess current results and the need for further changes. A marketing strategy can almost never be implemented in its original form - it can and should be adjusted in response to continuous changes in the environment. It is recommended to review (and make necessary adjustments) the developed strategy, according to the methodology of the PROMIS Project, annually. Experts from various fields should be involved in monitoring the implementation of the strategy for the sake of completeness and constructive judgments [7]. The positive image of the region created as a result of the use of marketing tools will be a long-term tool designed for a strategic perspective.

The main means of creating a regional image are the media, $\mathrm{TV}$, radio, special publications with a proper rating and the Internet. It is important to note that a huge role in the development of the region's image is played by the media, which create and effectively apply stereotypes and images [10]. Questionnaires of the region's image are its inhabitants, although a large number of people with different worldviews find it difficult to find a single idea of the long-awaited result. Therefore, to develop and promote the image of the region is a long and predictable process that is difficult to define. Thus, the image of the region is most often formed by public authorities [3].

Central print media and television channels are popular media, but are too difficult to place for free, and are the most expensive communication channel for paid advertising.

The set of regional mass media (regional and city publications, regional and city TV channels, local radio) forms another group of mass media with a strong informational influence on the target groups. A significant proportion of people prefer the local media, as informing the local media is adapted to the needs of the resident.

Extrapolating the Polish experience to Ukrainian realities, the authors [11] single out two possibilities that give local publications an advantage over national ones and are able to tie the reader to them: 1) ensuring the reader's connection with a community and giving the opportunity to influence reality through the media (spreading the trend of so-called "involved" journalism with the creation of content for communities and in their interests); 2) coverage of the course of reforms, interpretation of their significance and opportunities for the Ukrainian audience.

In the conditions of globalization changes and in the Ukrainian realities of regional division and a certain regional confrontation, such a function of local media as the formation and maintenance of local identity is actualized, but with the preservation of national values. It is thanks to the professional local media that the region can broadcast information about its own uniqueness and importance, irreplaceability on a national scale. Moreover, there are many opportunities to communicate about themselves both on the rich historical foundation of the region (which, for example, can reveal their tourism potential) and broadcast information about modern interesting and successful business projects [12].

The researcher [13] qualifies the media as a key element of geobranding communications, emphasizing their dual nature: as consumers of geobranding and as members of a special group of stakeholders responsible for shaping the image of the territory. It proves the expediency of high-quality regional and local media projects as translators and interpreters of the benefits of territorial education. Local publications cannot be limited to news reports. The peculiarity of media communication with the audience is provided by various formats, based on real people, their life stories (problems and ways to overcome them).

Currently, a steady demand has formed for useful information for users, not a message about the problem, but a proposal to overcome it. This journalistic trend is called "constructive journalism". At the heart of this format is the desire to show more background news to better inform people and give them a realistic view of the world around them. According to researchers from Denmark, constructive journalism can be effective in uniting local communities and 
reducing polarization in society through negative news. The media should become a platform for informing about innovations, about the opportunities of the region, business structure, individual. This will attract investors, active and creative people who are able to participate in the development of the location [1].

A separate issue is the aspect of using digital and interactive technologies in the formation of the image of the regions, in particular the distribution of interactive content. Today, such technologies work successfully in the business environment and should be used to improve the image of the region. If before the emergence and dissemination of blogs, social networks, forums, the image of the region was formed as a result of the perception of information only from the media (media image), nowadays the so-called "network image of the territory" becomes relevant [14]. Simon Anholt, a well-known researcher of regional branding, the author of the concept of competitive identity, pointed out that to form a positive image of the territory is not enough to artificially shape the image only through marketing communications and creativity. It is necessary to actively and fundamentally work to ensure that the city benefits people, attracting modern branding tools: the development of tourist and investment attractiveness, motivation for talented people, the organization of large events, cultural exchange, etc. [15]. The achievements of the digital economy must be used for this. Social networks are not only a new form of media or a form of content search and filtering - it is a modern form of public and mass communication, which is primarily characterized by interactivity (the relationship of all participants in communication) [16].

Thus, the factors that will ensure the successful implementation of the process of forming the image of the region are:

1) the strength and attractiveness of the regions in their uniqueness and dissimilarity, so it is necessary to identify and emphasize the exceptional offer;

2) multi-vector information policy with a wide range of tools is the most important component of a successful image of the region;

3) there should always be local residents in the groups of the target audience;

4) the formation of the image of the region is a collective work and social partnership;

5) the process of forming the image of the region should not be static, it should change in accordance with the development of the region;

6) increasing the information components in the process of creating the image of the region increases the importance of the region, gives it a new understanding within the effective use of the potential of the territories.

Conclusions. Regions, as socio-economic systems, are in modern conditions the main engine of market relations and business communications, the basis for the development and use of all aggregate production capacity capable of forming a new type of competitive advantage. The need to form the competitive advantages of regions based on the use of priorities of innovative economy, determines the feasibility of forming new tools to manage their socioeconomic development, one of which is the formation of a positive image of the regions. The formation of a positive image allows you to create a unique image of the region on the basis of the formation of its competitive advantages, develop the business environment of the region and attract the resources necessary for effective regional development $[2]$.

A positive and well-built image can act as one of the tools to attract investment aimed at the development of territories and the achievement of sustainable development goals. Experience has shown that those communities and territories that gradually implement interconnected marketing activities are more successful. They are much easier to achieve the goals of sustainable economic development, in particular:

- attraction of investments and creation of new enterprises;

- preservation and expansion of existing enterprises, increase in the number of jobs;

- improving the image at the local, national and international levels, launching mutually beneficial partnerships;

- attracting new residents and improving the well-being of the community as a whole;

- increasing the number of tourists; population.

- popularization of political decisions and programs among the community, gaining the support of the

The image of the region provides the conditions for successful implementation of reforms of social and economic orientation, activity and conflict-free entry into globalization processes. Thus, an understanding of territorial identity at the level of communications and technologies of social consolidation is formed. Problems of forming a positive image of the regions require detailed study and are a topical issue of modern development of the country from the standpoint of influence on the processes of economic and social progress.

\section{References.}

1. Zykun, N. (2020), "Local mass media and image formation of Ukrainian regions", Image and reputation: current trends and challenges: international. scientific-practical conf, Kyiv, Ukraine, pp. 66-75.

2. Vasilkonova, E.O. (2016), "Management of the region's development on the basis of forming its positive image", Abstract of Ph.D. dissertation, Development of productive forces and regional economy, Cherkasy State Technological University, Cherkasy, Ukraine. 
3. Shoturma, N.V (2015), "Image of the region as a component of the state information policy of Ukraine", State and regions, Series: Public Administration, vol. 1 (49), pp. 81-85.

4. Szromnik, A. (2007). Marketing terytorialny. Miasto i region na rynku [Territorial marketing. The city and the region on the market], Oficyna Wolters Kluwer, Kraków, Poland,.

5. Sadovyi, V.O. Mohylna, N.O. and Omelianenko, V.A. (2009), "The image of the region as a factor in attracting foreign and domestic investment”, Mechanism of economic regulation, vol. 3, pp. 282-287.

6. Konyk, D. and Suslenko, A. (2017), "Communication strategy for the city of Ivano-Frankivsk", available at: http://pleddg.org.ua/wp-content/uploads/2019/11/IF-Communication-Strategy.pdf (Accessed 2 April 2021).

7. Federation of Canadian Municipalities. Partnership for Urban Development International Technical Assistance Project (2019), "Case study: Branding and marketing of territories", available at: http://pleddg.org.ua/wpcontent/uploads/2019/09/Case_Study_PLEDDG_Regional_BrandingMarketing_2019.pdf (Accessed 12 April 2021).

8. Wróblewski, Ł. (2016). "Creating an image of a region - Euroregion Beskydy and Euroregion Cieszyn Silesia examples", Economics and Management, vol. 8, no. 1, pp. 91-100.

9. Balueva, O.V. and Rybachenko, T.Yu. (2014), "Formation of the image of territories in the context of sustainable development”, Economics and organization of management, vol. 3 (19) - 4 (20).

10. Khizhnyak, L.M. (2009), "Constructing the image of the region as a way out of the socio-economic crisis", Social technologies, vol. 42.

11. Kulina, K. (2021), "Local press: what can we learn in Poland?", available at: http://old.cedem.org.ua/analytics/mistseva-presa-chogo-my-mozhemonavchytysya-u-polshhi/ (Accessed 12 March 2021).

12. Matviyenko, S.M. (2017), "Regional mass media as a tool for forming local identity", Political life, vol. 4 , pp. 83-86.

13. Voronova, V. (2018), "Route №1" of the newspaper "Day" in the context of the implementation of geobranding tasks", Image: scientific journal, vol. 2 (28), pp. 109-117.

14. Kolyadenko, S.V. (2018), "Digital economy as a basis for forming a positive potential of the image of the region of Ukraine", Economy. Finances. Management: current issues of science and practice, vol. 10. pp. 32-40.

15. Anholt, S. (2010), Places: Identity, Image and Reputation, Palgrave Macmillan, New York, USA.

16. Pugach, L.Yu. (2019), "Socio-communication components of the communicative model", Young scientist, vol. 1 (65). DOI: https://doi.org/10.32839/2304-5809/2019-1-65-34 